\title{
A LOOK AT WOMEN'S TRANSITION FROM FORMAL LABOR TO SELF-EMPLOYMENT BASED ON ENDOGENOUS STIMULI
}

\author{
GISÉLIA F. FERREIRA, SÉRGIO A. P. BASTOS, AND MARCIA J. D'ANGELO \\ Fundação Instituto Capixaba de Pesquisas em Contabilidade, \\ Economia e Finanças (Fucape), Vitória, ES, Brazil
}

To cite this paper: Ferreira, G. F., Bastos, S. A. P., \& d'Angelo, M. J. (2018). A look at women's transition from formal labor to self-employment based on endogenous stimuli. Revista de Administração Mackenzie, 19(2). doi:10.1590/1678-6971/eRAMG180086

Submission: Aug. 2, 2017. Acceptance: Oct. 28, 2017.

\section{(cc) $\mathbf{B Y}$} This is an open-access article distributed under the terms of the Creative Commons Attribution License.

\footnotetext{
This paper may be copied, distributed, displayed, transmitted or adapted if provided, in a clear and explicit way, the name of the journal, the edition, the year and the pages on which the paper was originally published, but not suggesting that RAM endorses paper reuse. This licensing term should be made explicit in cases of reuse or distribution to third parties. It is not allowed the use for commercial purposes.

Este artigo pode ser copiado, distribuído, exibido, transmitido ou adaptado desde que citados, de forma clara e explícita, o nome da revista, a edição, o ano e as páginas nas quais o artigo foi publicado originalmente, mas sem sugerir que a RAM endosse a reutilização do artigo. Esse termo de licenciamento deve ser explicitado para os casos de reutilização ou distribuição para terceiros. Não é permitido o uso para fins comerciais.
} 


\section{ABSTRACT}

Purpose: The objective of this study is to analyze the stimuli that lead women to leave formal jobs and seek self-employment.

Originality/value: Changes in the social patterns and lifestyle of the population have made research aimed at career and gender gain relevance. There is, however, a lack of research on women who have left their organizations and the main stimuli of this movement, exogenously and endogenously driven, which are relevant as result of social and cultural factors intrinsic to the family environment that leads to a career change.

Design/methodology/approach: The qualitative methodology of narrative analysis was used, adequate to the examination of the phenomenon in question.

Findings: The following stimuli were highlighted: self-fulfillment and search for flexibility; professional achievement; personal challenges; high level of career ambition; and search for a feminine identity. The results diverged in relation to the existing literature, mainly focused on exogenous factors. Although mentioning difficulties in reconciling work with domestic activities, the professionals under study, previously occupying formal positions in companies, did not perceive or did not undergo any type of limitation at work, such as the phenomenon of glass ceiling, difficulties in working on the masculinized leadership model, family pressures, and fear of misuse of sexuality. Entrepreneurship emerged mainly as a career option as a form of personal self-actualization and not through imposition arising from social, family or labor difficulties.

\section{KEYWORDS}

Female entrepreneurship. Self-employment. Narrative analysis. Career transition. Endogenous stimuli. 


\section{INTRODUCTION}

The constant changes in the world scenario, especially to the new social standards and lifestyle of the population, have made research aimed at career and gender gain strength (Stefanović \& Stošić, 2012). This is even more relevant regarding women's work, especially the transition from formal employment to self-employment, which can be stimulated by barriers that women encounter in the labor market, leading them to rethink their careers within organizations (McGowan, Redeker, Cooper, \& Greenan, 2012).

Each professional has their own process of career transition and the evolution to entrepreneurial practices leads to the need to know their challenges and profiles (Vinnicombe \& Bank, 2003). Highlighting women's entrepreneurship is not recent (Hirisch, 1986), neither is recognizing the importance of a deeper understanding and identification of causes in mobility in women's careers (Metz, 2005).

It should be noted that the gender issue in organizations has been addressed in the literature in several areas, such as: the perception that organizations are not gender neutral (Acker, 1990); the construction of the feminine identity in the work environment impacts the development of their careers in certain organizational conditions (Ely, 1995); there are pioneer women occupying organizational positions historically considered masculine (Acker, 2008); and gender constraints imply career consequences for men and women, including in the capitalist arena and globalization (Acker, 2004).

It is also important to highlight the importance of feminist and multicultural approaches in management research (Cerchiaro, Ayrosa, \& Zouain, 2009). According to Cálas \& Smirich (1999), to understand contemporary society and its organizations, it is necessary to recognize the historical condition of oppression of women and to introduce their points of view into organizational discussions.

Although several studies show the salience of exogenous stimuli to women's professional mobility (Kumra \& Vinnicombe, 2008; Guillaume \& Pohic, 2009; Carvalho Neto, Tanure, \& Andrade, 2010; Oltramari \& Grisci, 2014), it is argued that a more subjective and endogenous stimulus is underestimated and relevant to be explored.

Even with the significant increase in studies on female entrepreneurship, including Brazilian production on the subject, those studies were stuck to an approach of competency analysis and the characteristics present in the way of managing women, often limiting to present a profile of the 
entrepreneurial woman (Gomes, Santana, Araújo, \& Martins, 2014). Thus, in the face of the growth of female entrepreneurship, academic literature has paid little attention to the social and cultural factors that are intrinsic to the family environment and that lead to a career change for women (Røsen, 2014). There is evidence that women's motivations to self-employment are different from those of men, with women affected, mainly, by family concerns and men with larger monetary gains opportunity (Allen \& Curington, 2014).

Additionally, gender segregation in the labor market still exists and ultimately stimulates women to self-employment (Zhang \& Pan, 2012). However there are still doubts about the causal relationship between self-employment among women and the work situation (workload and selfemployment) of their partners (Røsen, 2014). Therefore, the objective of this study is to identify stimuli that lead women to choose to leave a formal job and a career on the rise and migrate to self-employment. We can observe that an increase in the academic interest on the proposed theme would correct "historical inattention to women's entrepreneurial activity" (Hughes, Jennings, Brush, Carter, \& Welter, 2012, p. 430).

\section{THEORETICAL FRAMEWORK}

For a long time, society has used the biological difference argument to explain inequality between men and women in the labor market, for considering women as incapable (Amorim \& Batista, 2012). However, studies showed that boys have slower development and are "lagging behind" (Eliote, 2010).

In Brazil, in 2015, the population was composed of $51.6 \%$ of women and $48.4 \%$ of men, with women accounting for $43.8 \%$ of the economically active population and about $61.8 \%$ of employed women are between 25 and 49 years of age. The growth of female schooling is a factor that is being consolidated. Considering the population aged 25 years and over, the average number of years of schooling among women is 8.1 years, whereas among men it is 7.7 years. It is also noteworthy to mention, data pointing to women as references (livelihood providers) to $40.5 \%$ of families (IBGE, 2015).

The literature on business administration has addressed the issue of the construction of female identity in the workplace, impacting the development of their careers in certain organizational conditions (Ely, 1995). The pioneering of women occupying male-dominated organizational positions, including in academia, is still the subject of recent studies (Acker, 2008), 
notably through the perception that organizations are not gender neutral (Acker, 1990). Gender constraints can have consequences on the career of men and women in organizations, including in the capitalist arena and globalization (Acker, 2004).

It is also pertinent to emphasize the importance of feminist and multicultural approaches in management research (Cerchiaro et al., 2009), that is, giving prominence to rejected or stereotyped voices present in management's mainstream literature. In the case of male/emale dualism, questioning the association between the supposed objectivity of men and the supposed subjectivity of women, which leads them to have their roles minimized in organizations (Calás \& Smircich, 1999). Also, according to Cálas and Smirich (1999), to understand contemporary society, one must recognize the historical condition of oppression of women and introduce their points of view in the organizational studies.

A careful look at the situation of women in companies registers the feminization of management functions (Guillaume \& Pochic, 2009). In this scenario, women are in the challenge of reconciling work and home. Thus, self-employment appears as a career alternative, standing out for the apparent benefit of allowing greater control over the time and professional future (Lindo, Cardoso, Rodrigues, \& Wetzel, 2007).

Changes in the labor market, especially the migration of women who leave private companies and seek self-employment, have become the target of several studies (Stefanović \& Stošić, 2012; Amorim \& Batista, 2012; Vale, Serafim, \& Teodósio, 2011; Okafor \& Amalu, 2010; Minniti, 2010; Jonathan, 2005), but concrete indications about the real stimuli that drive women to make such a move are still insufficient (Røsen, 2014; Allen \& Curington, 2014).

The narratives of women are placed in different orders, being responsible for the change of the subject and constituting the feminine identity, being submissive to specific moments in their history and "harboring particular experiences, emotions and cultural experiences that allow the social construction of the subjectivity of women" (Vieira, 2005, p. 2010). Taking this context into a subjective organizational narrative, Vasconcelos, Mascarenhas, and Zacarelli (2006) point out perceptions of the social actors in the conditions of change, that cause a reconstruction of the meaning of their experiences, from the mutations that they experience in the succession of their days.

Men and women experience leadership positions differently in such a way that men's careers tend to be linear, while those of women are 
characterized by interruptions and exits (Ezzedeen \& Ritchey, 2009). In addition, women are not reaching the top of business management, despite having similar educational levels - referring to the "glass ceiling" phenomenon. Such difficulty may lead them to rethink their careers within formal organizations (Kumra \& Vinnicombe, 2008). Paradoxically, Marques and Moreira (2011) show that, in the labor market, there is a significant increase in female presence.-

Another difficulty encountered by women in the labor market relates to sexuality and the fear of its misuse in the organizational environment. There is a prejudice against women who reach senior positions either by supposedly, having benefited from their sexuality, or whether by adopting a masculine behavior (Carvalho Neto et al., 2010).

In a competitive labor market, those who seek professional growth and aim to build a career in high-management positions, feel the need to "considerably increase their workload as well as their responsibilities" (Oltramari \& Grisci, 2014, p. 18). Positions at high levels of seniority also require a high degree of functional and geographical mobility. The woman who manages her career for ascending growth encounters this scenario and finds it difficult to combine paid and unpaid work in the current models of horizontal promotion (Guillaume \& Pohic, 2009).

A more subjective view of contemporary organizations indicates that in the management of constant change people begin to "make attempts to explore new opportunities and establish a new balance, to redefine oneself through a process of self-examination" (Silva \& Vergara, 2003, p. 14). The first work and family conflicts occurred when women began to share their role as mother and housewife with labor market activities, emphasizing the incompatibility, in some respects, of such conflicts (Parasuraman \& Greenhaus, 1997).

The contemporary workforce is characterized by a significant increase in women, in couples of dual incomes and with children, which implies needs related to time, work configuration and roles in the family (Piszczek \& Berg, 2014; Lindo et al., 2007). Such difficulties are not only felt by women, although they are intensified in them, according to the social variables and responsibilities they occupy (Ferreira \& Nogueira, 2013).

Studies on boundaryless assume that organizations are no longer able to offer workers stability in employment and progressive careers, evolving towards the end of traditional careers (Rodrigues \& Guest, 2010). The search for boundaryless careers is the possibility of greater flexibility, the supposed disappearance of rigid work structures and hierarchical career paths (Briscoe \& Hall, 2006 apud Rodrigues \& Guest, 2010). 
Studies by Grady and McCarthy (2008) highlight that working mothers were looking for an occupation that gave them more time to balance the equation "work, family and personal well-being". Moreover, in the studies by Carvalho Neto et al. (2010), the possibility that the female professional failure has a lower weight than the male is stressed.

Work can be a way for the female gender to resist male attacks on their identity, since the prestige within this capitalist market lies in who holds the economic superiority, which may lead women to try to reconcile their profession with housework, since the woman who does not work is destined to the role of being supported, of subjugation to the power of the husband or partner (Vieira, 2005).

On the other hand, the struggle of women to equate men's work is not benefiting them, but by masculinizing them, and the fact that women work in equal numbers of hours and with the same functions and responsibilities as men are not necessarily liberating them, but keeping them in double working hours (Vieira, 2005). The structure of organizations today is often the consequence of a model in which managers and leaders forget or ignore the lives of employees outside of work (Kreiner, Hollensbe, \& Sheep, 2009).

In this scenario, the feeling of guilt emerges (Carvalho Neto et al., 2010). Some working mothers adopt individual tactics in building a better work-home balance, in view of the difficulty in reconciling family activities with their careers (Araujo et al., 2015). Women, besides the activities inherent to their position in a company, have large domestic responsibilities and they need "to seek strategies to mitigate the conflicts between these important instances of their lives" (Lindo et al., 2007).

Grady and McCarthy (2008) emphasize the feeling of motherhood, in which the children are the number one priority, without leaving aside the career, coexisting with the search for stimuli, challenges, achievements and enrichment. The belief that a woman's ambition disappears when children arrive is denied by Dikkers et al. (2010).

The search for entrepreneurship is not necessarily a greater challenge or result of guilt, but it can also be an attempt to construct a new identity in the face of external changes and also as a form of social transformation (Vasconcelos et al., 2006; Vieira, 2005).

Entrepreneurship can be an alternative for women who become mothers and seek to reconcile motherhood and career, "one of the possible routes to the labor market" (Marques \& Moreira, 2011, p. 433), i.e., an alternative of career transition. Maternity can influence the perception of the career transition from the corporate world to self-employment (Lewis, 2015). 
Entrepreneurship and self-employment are often listed and cited as complementary (Robalo, 2015) or as two interconnected concepts, treated in the imaginary of the population as synonyms, without clear distinction between the two terms (Silva \& Vergara, 2003). The word entrepreneurship is derived from the French "entreprendre", conceptualizing entrepreneurship as the force of making happen, of generating something new (Dornelas, 2008). However, we can perceive that the word entrepreneurship has a broader meaning and is related to several themes besides the creation of companies, often being used to conceptualize personal characteristics (Ferreira, Santos, Serra, \& Reis, 2010). The entrepreneur can also be the employee who develops innovative practices in a company, also called intrapreneur (Drucker, 1994). For the purposes of this study, we used the term self-employment as described by Robalo (2015), as referring to those who are self-employed, who do not necessarily generate innovative ventures. In this case, considering Singh and DeNoble (2003), self-employment is characterized as a simpler form of entrepreneurship.

Stimulus and motivation of these women for self-employment can vary significantly. This is what Okafor and Amalu (2010) point out when they listed factors such as frustration, dissatisfaction at work, divorce, boredom, search for independence, autonomy, education and family security.

Mainiero and Sullivan (2005) claim that qualified women, with high potential for management positions, have been leaving the corporate sphere, causing alarm and at the same time generating controversy. They are welltrained women who choose not to pursue a formal corporate career. At this point, the careers of these women are compared to a kaleidoscope that "produces the change of patterns when the tube is rotated and its glass chips fall into new arrangements" (Mainiero \& Sullivan, 2005, p. 106).

Earlier studies on female entrepreneurship pointed out that the main motivations for women to open their own business were the same as for men: success, independence, economic reward and job satisfaction (Schwartz, 1976). Regarding the barriers, the fact of not having a partner at the time of setting up a business seems to have a positive influence on the ambition to start it (Akehurst, Simarro, \& Mas-Tur, 2012). Entrepreneurial stimuli are more manifest when family support exists, as well as when the spouse or any close family member already owns a business (Akehurst et al., 2012). The stimuli and motives in opening their own business among women result more from the influence of another person $(21 \%)$ in relation to men (7\%) (Vale et al., 2011).

A research conducted with ten entrepreneur women who recently had left managerial positions in large UK companies to start their own ventures, 
also revealed the anxiety they had to advance their careers as businesswomen, even having companies interested in keeping these women on their boards (Terjesen, 2005). This study is consistent with the research by Dikkers et al. (2010), which shows that women have ambitions and are looking for career growth.

Vinnicombe and Bank (2003) highlighted the main motivations for the growth of women leaving the corporate environment: wage inequalities, career frustration due to "glass ceilings" and the promise of flexibility in entrepreneurship. The results of the research by Leung (2011), carried out with women and female entrepreneurs in Japan, stresses the importance of motherhood, and how they take the mother-family role along the entrepreneurial path.

As for the motivation for the entrepreneurial activity, for women, the difficulty in obtaining employment and a better conciliation between family and career appear as stronger reasons to start a company, while for men, the motivation is the opportunity of new challenges and the prospect of making more money (Marques \& Moreira, 2011). These data are also pointed out in the research by Vale et al. (2011), which shows that, in the case of men, the reason "opportunity" was relatively higher: $50 \%$ against $34 \%$ for women.

Lewis (2015) highlighted how maternity can have a marked influence in the career transition from corporate to self-employment. Her objective was to use the definition of "boundaryless career" as a perspective to explore the understanding related to the life stage of motherhood with the transition to self-employment, as a form of autonomy in the work scenario, with incomes and continuous professional identities. According to McKie, Biese and Jyrkinen (2013), in turn, by opting for self-employment, women are trying to create a career that lays the foundation for gender relations and allows "the cultivation of a more enjoyable scenario through which they can cross to a next phase of their career". Understanding stimuli and motivations on female entrepreneurship is important in understanding the significance of the role of women, not only in the creation, but also in the execution and growth of business as an impacting factor in the economic growth of a society (Acs, Bardasi, Estrin, \& Svejnar, 2011).

Women in developed economies are more likely to start businesses due to the opportunity factor, while those living in economically less developed countries are motivated by the need (McGowan et al., 2012; Brush \& Cooper, 2012). Minniti and Naudé (2010) show that female entrepreneurship prevalence rates tend to be relatively higher in developing countries than in developed countries because of greater barriers to entry into the formal labor market. 
Finally, Ferreira and Nogueira (2013) assert that there are no specific and universal reasons justifying the quest to start their own business. However, reasons for this search can also be an alternative positioning in the face of external changes caused by political, social and economic issues. Women, as social actors, see their lives affected by internal changes as well, in the search for their feminine identity as a professional (Vieira, 2005). The perception of time and space of these women, from the changes of their working conditions, somehow affects the senses that these professionals attribute to the lived experience (Vasconcelos et. al., 2006).

\section{METHODOLOGY}

The study is exploratory, since it is carried out in an area of little accumulated and systematized knowledge, which is the case of the transition from executive women's careers to self-employment, considering the variety of possible stimuli in this process. It also has a descriptive character, since it exposes characteristics of the current phenomenon with complex variables of the social, economic and business environment. The method we use is qualitative, using narrative analysis, under the terms proposed by Riessman and Quinney (2005).

A total of 12 entrepreneurs were interviewed, from the state of Espírito Santo, Brazil, aged between 28 and 47 years. The number of interviews is due to the saturation of data, in which what was narrated began to repeat itself. Data was collected in the first semester of 2016. All the interviewees had formal jobs in private companies in various positions before becoming entrepreneurs. The interviews were recorded and transcribed, with the proper authorization of the interviewees. In the process of managing and analyzing the narratives, we used the NVivo software.

The qualitative approach is presented as an adequate and relevant alternative when seeking a greater plurality of the interviewees' spheres of life (Flick, 2009). According to Godoy (1995), in this approach, the direct and prolonged contact of the researcher with the environment and the situation under study is valued. Considering that the phenomenon under study is still little explored, the qualitative approach is "capable to capture the richness of its meaning" (Lindo et al., 2007, p. 106). Both the narrative and the stories report sequences (chronologies) of events, but with the narrative there is more attention to the order and import of events, adding coherence to the narrative. That is, the narration makes the events come to 
exist in a discursive way (Boje, 2001). Aiming at listening from the perspective of the interviewee, here the qualitative research seeks to investigate the particularities of the interviewees, the how and the why of the facts (Cassell \& Symon, 2004).

We also used what is suggested by Schütze (2010) as important parts of the process: 1 . let them talk, when the interviewee sets out their initial perceptions about the proposed theme, 2 . tie the lost threads, when the researcher seeks to clarify some doubts; and 3. to suggest the reasons why, characterized when the researcher makes brief descriptions of situations that may have gone unnoticed, repeated in the interviewee's narrative.

We used a semi-structured questionnaire, although during interviews the interviewees themselves anticipated the prepared questions, following a spontaneous sequence of narrative. Here, we need a contextualization: the environment in which the interviews took place may have influenced a narrative that is mostly directed to their professions and their business. The personification of the businesswoman was perceptible, sitting at a large table, talking about her choices. This does not mean that there was any inducement caused by the environment, but rather the ratification of a role that was assumed at the time. Emphasis was placed on motivations for career migration, whether by a personal choice in their career planning, or whether the movement was imposed on them by external issues, such as the difficulty of ascending in the formal labor market or the need to reconcile more flexible work due to the double journey, reinforced by maternity. The characteristics of the women interviewed are shown in Table 3.1.

\section{(Table 3.1)}

\section{CHARACTERIZATION OF INTERVIEWEES}

\begin{tabular}{cclcccc} 
Interviewee & Age & $\begin{array}{c}\text { Educational } \\
\text { Background }\end{array}$ & $\begin{array}{c}\text { Number of } \\
\text { Children }\end{array}$ & $\begin{array}{c}\text { Marital } \\
\text { Status }\end{array}$ & $\begin{array}{c}\text { Sector } \\
\text { of the } \\
\text { Company }\end{array}$ & $\begin{array}{c}\text { Time in } \\
\text { the New } \\
\text { Occupation }\end{array}$ \\
\hline A & 36 & Postgraduate & 2 & Married & Service & 2 years \\
\hline B & 39 & Postgraduate & 3 & Married & Service & 6 years \\
\hline C & 35 & Postgraduate & 2 & Married & Service & 5 months \\
\hline D & 47 & Higher Education & 3 & Married & Industry & 8 years \\
\hline E & 38 & Postgraduate & 1 & Divorced & Service & 5 years \\
\hline
\end{tabular}




\section{(Table 3.1 (conclusion))}

\section{CHARACTERIZATION OF INTERVIEWEES}

\begin{tabular}{ccccccc}
\hline Interviewee & Age & $\begin{array}{c}\text { Educational } \\
\text { Background }\end{array}$ & $\begin{array}{c}\text { Number of } \\
\text { Children }\end{array}$ & $\begin{array}{c}\text { Marital } \\
\text { Status }\end{array}$ & $\begin{array}{c}\text { Sector } \\
\text { of the } \\
\text { Company }\end{array}$ & $\begin{array}{c}\text { Time in } \\
\text { the New } \\
\text { Occupation }\end{array}$ \\
\hline$F$ & 30 & Higher Education & 1 & Married & Trade & 2 years \\
\hline$G$ & 45 & Postgraduate & 3 & Divorced & Service & 7 years \\
\hline$H$ & 38 & Higher Education & None & Married & Service & 3 years \\
\hline I & 43 & Higher Education & 2 & Married & Trade & 1 year \\
\hline$L$ & 28 & Higher Education & None & Married & Trade & 7 months \\
\hline$M$ & 37 & Postgraduate & 1 & Married & Service & 2 years \\
\hline & 34 & Postgraduate & None & Married & Service & 3 years \\
\hline
\end{tabular}

Source: Elaborated by the authors.

\section{RESULTS AND ANALYSIS}

\subsection{Self-fulfillment and search for greater flexibility}

Similarities in the narratives could be verified, especially when the interviewees explained about the relationship with their formal work before becoming entrepreneurs. No one presented any type of difficulty in relation to their feminine gender regarding management positions, contradicting the perception that organizations are not gender neutral (Acker, 1990) and that women would have greater difficulties in relation to men(Carvalho et al., 2010). Interviewee $C$ said that in her later work, she held management positions in areas such as financial and accounting. The relationship required excessive commitment, without caring about the return home, if the company needed more workload. Interviewee D, in turn, tatted: "I worked as an administrator in a medium sized company and stayed there for 9 years. It is quite a while". The strong relationship with the employer was also attested by interviewee B: "I started working very early. My relationship with work, the companies I passed through always required an owner perspective of me, even if I was not". Satisfaction with the previous work was, in general, evident: 
I worked as a regular employer for 3 years, and then worked as an Administrator at a large company. In this job I had a commissioned position and worked 8 hours a day. I really liked what I did, I learned a lot from both companies (Interviewee A).

In the first part of the interviews, it could be identified that these mothers did not have a history of difficulties in the work-company relationship, with formal employment experiences being described pleasantly. The barriers presented in the contextualization of the current labor market scenario, such as the "glass ceiling" phenomenon cited by Kunra and Vinnincombe (2008), mainly for female labor, were not identified with these women. Another point not identified in the narratives and quoted in the theoretical framework is the statement by Carvalho Neto et al. (2010), on the fear of women in the misuse of sexuality in the organizational environment.

The satisfaction with the previous work presented by interviewee $G$ is justified with a sense of frustration related to the boss:

I had a great team, as a manager I felt fulfilled. However, the relationship with my immediate superior was getting worse and worse. I didn't get along with him, he was always picking at small things and I think he was afraid of losing his role to me. Since the company did not take due action, I decided to leave. It was something I was looking for too (Interviewee G).

However, out of all the interviewees, only interviewee B had well defined plans for her career. The desire to have her own company was always there, adding even, the fact that the current company is the third company she started. However, the career history of these women reinforces the theoretical contextualization that there are organizational constraints with consequences in men's and women's career developments (Acker, 2004), and that men possess a more linear career, while women are characterized by interruptions and exits, as quoted by Ezzedeen and Ritchey (2009). It is worth adding that these interruptions are placed in the narrative as something natural and did not represent threats or annoyances.

Most interviewees did not have a defined career plan before they became mothers. They sought fixed formal employment, with stability, opportunity for growth and attractive remuneration. However, even without formal planning, we can observe in the narrative that they had an interest in self-employment, although it was not strong enough to 
materialize it. This position is exemplified by interviewee D: "At the time of my pregnancy I did work and hoped to stay in the company for a long time. But I had it in my head to set up my company". Also as an example of similar posture:

At the time of my pregnancy I did work, but I was already thinking about a business as a consultant in market research, I left when I got pregnant. It was the moment I worked the least during my professional life. I did not have a defined career plan, but I already visualized my desire to be a businesswoman (Interviewee A).

These entrepreneurial mothers, except for interviewees B and L, began to rethink their careers with the arrival of their children in the face of the frustrations encountered. We perceive that the path of entrepreneurship was not the first option, nor the only one. These mothers moved to running business due to two main motivators: professional self-fulfillment and a search for greater flexibility to manage the work-family relationship. As evidenced in Lindo et al. (2007), entrepreneurship appeared as a career alternative, standing out for the apparent benefit of enabling greater control over time and professional future, allowing more time at home. But in addition to this flexibility, we saw on the other hand that family pressure is a factor that impacts career change decisions, as mentioned by Carvalho Neto et al. (2010). Another factor that leads women-mothers to open their own businesses is that, according to Lewis (2015), the women had the perception that having their own company would provide full autonomy in the work setting, an income, and a continuous professional identity.

\begin{abstract}
About a year after my second child was born, I wanted to return to the labor market very much, even if it sacrificed my family life. I did not want to feel unprofessional any longer and knew that the longer I went without working, the worse it would be for my career. And also, after some time back at work as an employee, I started to want more freedom, which does not mean less work. But I wanted to control my schedules and my activities (Interviewee A).
\end{abstract}

Interviewee $\mathrm{C}$ also objectively addressed that, although she had a good relationship with work, she sought entrepreneurship to soften this overwhelming commitment to work and to have more flexibility and time with the family: 
I returned home so late several times, that I did not find my children still awake, even though I left home before they even woke up. I started my own company precisely because I did not want this overwhelming commitment. When you have a business of your own, you work a lot, but without the commitment of fixed schedules and daily checkpoints. Not to mention that the last company I worked in required me to complete activities even on weekends (Interviewee C).

According to interviewee $\mathrm{D}$, the search for self-employment only materialized after the arrival of the second child, reconciling with the search for greater flexibility and an entrepreneurial opportunity:

At the birth of my first child, I stayed in the company. But from the birth of the second child I realized I needed more time at home to take care of the family and the house. I realized I needed to be more present at home and there was an opportunity to start my own company (Interviewee D).

\subsection{Professional achievement}

The difficulties of professional growth found in the labor market, as posed by Guillaume and Pochic (2009), were not the main factors for the exit of these women from their formal jobs. On the contrary, as highlighted by Acker (2008), there are women occupying male-dominated organizational positions, which was the case of several of the interviewed women. Professional achievement as the main stimulus was most strongly cited by B, who claimed to always have an entrepreneurial facet and the desire to start her own business, having already previously started three companies. The other entrepreneurial mothers, despite the professional accomplishment factor also appearing in their narratives, pointed out the desire of a job where they had greater freedom of the management of the schedules as a greater force.

The family, for most interviews, was highlighted as a stimulator to start their own business, which also appeared in the research by Akehurst et al. (2012) and Vale et al. (2011). Another important fact is that all interviewees were married when they decided to migrate to self-employment, affirming that the support of the companion both psychologically and financially, gave base for the change in the race career. This is consistent with the study by Akehurst et al. (2012), who argued that having a partner motivated the search for self-employment. 


\subsection{Personal challenges}

The statement by Grady and McCarthy (2008) was partially reinforced. The research also pointed to evidence of a strong sense of motherhood in which their children were their priority. However, they have also placed career in the same level of importance in their search for stimuli, challenges and personal fulfillment. The flexibility to reconcile career and family was pointed out by seven interviewees as a motivating factor. Although they liked the company and assumed executive positions, they were precise in narrating that the company's management model did not meet their needs.

I've always been very dedicated to the company, doing overtime and traveling. However, it was embarrassing when I needed to ask to leave early to pick up my child at school or even arrive later because of some family problem. I did not feel the company returning the same dedication I had with my job and this bothered me a lot (Interviewee F).

The management of household activities had little change after the transition from formal employment to self-employment, since the interviewed women continued to work alongside the labor market and always had helpers as maids, cleaners and nannies. The partners also acted actively in the labor market and there was no change in support for household activities after the transition. They were and still are the main responsible for the management of the activities of the house and always had a double workday. "The management of the house has always been my responsibility, but the execution is also divided with children, husband and the maid. Nothing has changed" (Interviewee B). Other narratives corroborate this perspective:

The housework administration is still done by me and my husband helps me sometimes. Even after I became a businesswoman I still take care of the housework and when necessary I call a cleaning lady to do the job (Interviewee D).

The administration of domestic work is still done by me, but I have always had help from a maid. My husband only helps with the financial part; he leaves early and arrives late at home. I do not have a nanny anymore, but I did have one until my younger daughter was 4 years old (Interviewee A). 
Before I had a business of my own, I had a permanent maid working 44 hours a week, so I did not worry about housework. Nowadays, I hire a cleaning lady twice a week. Since I still have only a few clients, a good part of my time is free, making it possible for me to make commitments to the activities of home and children (Interviewee C).

\subsection{High level of career ambition}

A reinforced point in the research, cited in the theoretical framework, is the statement in the studies by Dikkers et al. (2010), which denies the belief that a woman's ambition disappears when children arrive. The interviewees show a high level of career ambition, even after the arrival of their children, additionally ratifying the studies by Mainiero and Sullivan (2005), which point out that qualified women with high potential for management positions have been leaving the corporate sphere. They are well-trained professionals who have chosen not to pursue a formal corporate career.

\subsection{Search for a feminine identity}

In a more subjective view of the narrative of these professionals, we evidenced an alignment to the studies by Ely (1995), when dealing with the impact in career development in certain organizational conditions, and Vieira (2005), when speaking of the construction of a new feminine identity in their relationship with the work facing the external transformations. The interviewees narrated professional trajectories while subjects of action and transformation of organizational changes, as pointed out by Silva and Vergara (2003). The feminine identity, added to the position of wife and mother, was sought in the decision-making process in the choice of their professional career. The vision of this new woman in the current labor market is clear, who seeks economic independence, which dictates new laws of the market including in their relationships with the masculine gender (Vieira, 2005).

For those who were employed, we questioned the position of the company regarding the outgoing communication and if there was any counterproposal by the company. All reported that the companies were surprised, questioned the reasons, but no active action was taken to keep them in the company. This passivity was presented in a more significant way by interviewees $\mathrm{D}$ and $\mathrm{F}$. This shows structured retention policies in the organizations in which they worked. 
As to the motivation for the entrepreneurial activity, the interviewees did not show great differences according to gender, as presented in the studies by Marques and Moreira (2011), and Schwartz (1976). This trend was evidenced in the narrative of these women, where all showed importance in having success, money and professional achievement. As an example, the following speech is highlighted:

I did not study this much to bear the problems I had in the last company. I knew I had the potential to go further, to earn much more than what they offered me (Interviewee G).

For the interviewees, the difficulty of obtaining employment was not the main factor in the search for self-employment, although the desire for a better reconciliation between family and career has been evident.

The analysis of the narrated subjectivity is also relevant, the unsaid content of these professionals, which expresses all the anguish of finding their feminine identity in their professional choices. This new professional also wants to choose and not only to be chosen. They want a job where they can have the power at hand, make their own decisions, support themselves without depending on the partner or family. In this view, entrepreneurship offers the encounter between the new feminine identity that is formed, in having favorable financial conditions within their values as women, and life quality regarding the flexibility in the responsibilities as a professional to take care of the house and children.

These professionals who migrated to entrepreneurship clearly narrate the search for their feminine identity in the labor market. They portray organizations that offered a formal job but were limited to workloads and similar functions to men.

That was not enough for these women, who saw in their old works only a masculinized repetition, which did not fulfill their desires in these changes of postmodernity. So, it could be evidenced what was highlighted by Cerchiaro et al. (2009): the importance of a feminist and multicultural approach in management research. Furthermore, as pointed by Cálas \& Smirich (1999), to understand contemporary society and its organizations, it is necessary to introduce the women's points of view into organizational discussions.

\section{FINAL CONSIDERATIONS}

The objective of this study was to investigate, within a broad field of study about contemporary issues about gender in organizations, the reasons 
which lead female professionals in prominent positions to leave formal corporate positions to migrate to self-employment, in the Brazilian context. It could be noticed that the stimulus to open their own business appeared more intensely from the necessity to find an activity that gave them greater freedom of schedules and, at the same time, satisfaction and recognition. These women sought to reconcile the need for more flexible work and a desire to leverage their careers by opening their own business. Although literature is richer to point exogenous stimuli, the research results showed the relevance of endogenous stimuli.

It was observed that the intention to have more time to devote to family activities was considered relevant. All interviewees had professional ambitions; they sought self-fulfillment through work, but did not exclude growth in a formal job. The arrival of the children, at first, did not consolidate as a decisive factor, nor the family pressures and the responsibilities of the home. The narrative on flexible work was based on the quest for life quality rather than on anguish or guilty feeling for not being together with the children.

Competitive labor market scenario, barrier to professional growth or family pressures: none of these items presented in the theoretical framework appeared in the narrative of the entrepreneurial mothers interviewed. The context of greatest occurrence was the construction of a better work-home balance. No market, family, or emotional pressures were imposed on these women. These entrepreneurial mothers went into self-employment in search of a better life quality, and also as a form of professional self-fulfillment.

Entering motherhood, at first, was not the main motivator for the search of entrepreneurship. Sequences of events intertwined the lives of these women, each having their own life history, which led them to similar professional paths in their careers. The stimuli were several, but these women knew what they wanted. Self-employment was a mature option over time, of which they are proud and foster new business growth. As a result, the following stimuli were highlighted: self-fulfillment and search for flexibility; professional achievement; personal challenges; high level of career ambition; and search for a feminine identity.

For future research, we suggest interviews in more neutral environments, other than at work or in the family context. It is possible that these women took a more professional role, enthusiastic about the work scenario in which they were. This posture could also have been involved by a narrative more inclined to family values if the interviews had been conducted in their homes, tending moreover to the mother role. 
Another limitation is the fact that the interviewees appeared to be in a good financial condition, besides a good schooling. Although we did not ask about the family income, nor was it an excluding aspect, these women had a structure that gave them greater stability to conduct their business, such as home assistants, nannies and children in full-time studies. In future research, the representation of female entrepreneurs from the less favored classes should be sought, which may lead to diverse or complementary results. We also suggest investigating the perspectives of companies that lose these women with developed skills and with potential for development. The organizational point of view would help to better understand how the management and retention of talent policies have been worked out.

We subtly observed, in the interviewees' narratives that, although they were satisfied with their own business, demonstrations of the difficulty in making their business profitable and that they are working as much as in the period that they had a formal job. Another suggestion of future research would be a more subjective analysis of the female identity and the organizational environment, since we perceived in many of the interviewees a narrative oriented in the search of their values, which were not taken care of in their old companies. A new research proposal would be to understand to what extent organizations are masculinizing these professionals and whether the transition could be a way of reuniting lost identity, but preserving the independence and power required in contemporary society.

\section{UM OLHAR SOBRE A TRANSIÇÃO DA MULHER DO TRABALHO FORMAL PARA O AUTÔNOMO A PARTIR DE ESTÍMULOS ENDÓGENOS}

\section{RESUMO}

Objetivo: O objetivo deste estudo é analisar os estímulos que levam mulheres a deixarem empregos formais a buscarem o auto emprego.

Originalidade/relevância: Mudanças nos padrões sociais e estilo de vida da população têm feito com que pesquisas direcionadas à carreira e ao gênero ganhem relevância. Existe, no entanto, carência em pesquisas sobre mulheres que tenham deixado suas organizações e os principais estímulos a esse movimento, de natureza exógena e endógena, que são relevantes 
como fatores sociais e culturais intrínsecos ao ambiente familiar e que levam a uma mudança de carreira.

Principais aspectos metodológicos: Foi utilizada a metodologia qualitativa de análise de narrativas, adequada ao exame do fenômeno em questão. Síntese dos principais resultados: Os resultados destacaram os seguintes estímulos: realização profissional e busca por flexibilidade; sucesso profissional; desafios pessoais; alta ambição nas carreiras; e busca por uma identidade feminina. Os resultados apontaram pontos de divergência em relação à literatura existente, principalmente focada em fatores exógenos. Embora narrando dificuldades em conciliar trabalho com as atividades domésticas, as profissionais objeto do estudo, previamente ocupantes de cargos formais em empresas, não perceberam ou não passaram por qualquer tipo de limitação no trabalho, como no fenômeno do teto de vidro, dificuldades em trabalhar no modelo de liderança masculinizada, pressões familiares e medo do uso indevido da sexualidade. O empreendedorismo aflorou, principalmente, como opção de carreira, como forma de autorrealização pessoal e não por imposição originada de dificuldades sociais, familiares ou trabalhistas.

\section{PALAVRAS-CHAVE}

Empreendedorismo feminino. Trabalho autônomo. Análise narrativa. Transição de carreira. Estímulos endógenos.

\section{REFERENCES}

Acs, Z., Bardasi E., Estrin, S., \& Svejnar, J. (2011). Introduction to special issue of small business economics on female entrepreneurship in developed and developing economies. Small Business Economics, 37(4), 393-396. doi:10.1007/ s11187-011-9372-1

Acker, J. (2004). Gender, capitalism and globalization. Critical Sociology, $30(1), 17-41$.

Acker, J. (2008). Helpful men and feminist support: More than double strangeness. Gender, Work and Organization, 15(3), 288-293. doi:10.1111/ j.1468-0432.2008.00393.x 
Acker, J. (1990). Hierarchies, jobs, bodies: A theory of gendered organizations. Gender \& Society, 4(2), 139-158.

Allen, W. D., \& Curington, W. P. (2014). The self-employment of men and women: What are their motivations? Journal of Labour Research, 35(2), 143-161. doi:10.1007/s12122-014-9176-6

Amorim, R. O., \& Batista, L. E. (2012). Empreendedorismo feminino: Razão do empreendimento. Núcleo de Pesquisa da FINAN, 3(3). Retrieved from http://uniesp.provisorio.ws/finan/pitagoras/downloads/numero3/> empreededorismo-feminino.pdf

Akehurst, G., Simarro, E., \& Mas-Tur, A. (2012). Women entrepreneurship in small service firms: Motivations, barriers and performance. Service Industries Journal, 32(15), 2489-2505. doi:10.1080/02642069.2012.677834

Boje, D. M. (2001). Narrative methods for organizational and communication research. London, UK: Sage Publication.

Brush, C. G., \& Cooper, S. Y. (2012). Female entrepreneurship and economic development: An international perspective. Entrepreneurship \& Regional Development, 24(1/2), 1-6. doi:10.1080/08985626.2012.637340

Calás, M. B.; Smircich, L. (1999). Do ponto de vista da mulher: Abordagens feministas em estudos organizacionais. In S. R., Clegg, C. Hardy, \& W., Nord (Orgs.), Handbook de Estudos Organizacionais (vol. 1). São Paulo, SP: Pioneira.

Carvalho Neto, A. M., Tanure, B., \& Andrade, J. (2010). Female executives: Career, motherhood, love and prejudice. Revista de Administração de Empresas, 9(1). doi:10.1590/S1676-56482010000100004

Cassell, C., \& Symon, G. (2004). Essential guide to qualitative methods in organizational research. London, UK: Sage Publications.

Cerchiaro, I.; Ayorosa, E. A. T.; Zouain, D. M. (2009). A aplicação de abordagens feministas na pesquisa em administração. Cadernos EBAPE.BR, 7(4), 650-664. doi:10.1590/S1679-39512009000400009

Dornelas, J. C. A. (2008). Empreendedorismo corporativo: como ser empreendedor, inovar e se diferenciar na sua empresa (2nd ed.) Rio de Janeiro, RJ: Elsevier.

Drucker, P. F. (1994). Inovação e espírito empreendedor (entrepreneurship): Prática e princípios. São Paulo, SP: Pioneira.

Eliote, L. (2010). Pink brain, blue brain: how small differences grow into troublesome gaps and what we can do about it. Oxford, UK: One World Publications.

Ely, R. J. (1995). The power in demography: Women's social constructions of gender identity at work. Academy of Management Journal, 38(3), 589-634. doi: $10.2307 / 256740$ 
Ezzedeen, S. R., \& Ritchey, K. G. (2009). Career advancement and family balance strategies of executive women. Gender in management: An international journal, 24(6), 388-411. doi:10.1108/17542410910980388

Ferreira, M. P., Santos, J. C., Serra, F. A. R., \& Reis, N. R. (2010). Entrepreneurship research: A bibliometric study of the EnANPADs 1997-2008. REBRAE, 3(1), 31-47.

Ferreira, J. M., \& Nogueira, E. E. S. (2013). Mulheres e suas histórias: Razão, sensibilidade e subjetividade no empreendedorismo feminino. Revista de Administração Contemporânea, 17(4), 398-417. doi:10.1590/S1415-6555 201300040002

Flick, U. (2009). Introdução à pesquisa qualitativa (3rd ed.) Porto Alegre, RS: Artmed.

Gomes, A. F., Santana, W. G. P., Araújo, U. A., \& Martins, C. M. F. (2014). Empreendedorismo feminino como sujeito de pesquisa. Revista Brasileira de Gestão de Negócios, 16(51), 319-342.

Guillaume, C., \& Pochic, S. (2009). What would you sacrifice? Access to top management and the work-life balance. Gender, Work and Organization, 16(1), 14-36. doi:10.111/j.1468-0432.2007.00354.x

Hughes, K. D., Jennings, J. E., Brush, C., Carter, S., \& Welter, F. (2012). Extending women's entrepreneurship research in new directions. Entrepreneurship: Theory \& Practice, 36(3), 429-442. doi:10.111/j.15406520.2012.00504.x

Instituto Brasileiro de Geografia e Estatística (IBGE) (2015). Pesquisa Nacional por Amostra de Domicílios 2014-2015. Retrieved from http://www.ibge. gov.br

Jonathan, E. G. (2005). Mulheres empreendedoras: Medos, conquistas e qualidade de vida. Psicologia em Estudo, 10(3), 373-382. doi: 10.1590/S141373722005000300005

Kreiner, G. E., Hollensbe, E. C., \& Sheep, M. L. (2009). Balancing borders and bridges: Negotiating the work-home interface via boundary work tactics. Academy of Management Journal, 52(4), 704-730. doi:10.5465/ AMJ.43669916

Kumra, S., \& Vinnicombe, S. (2008). A study of the promotion to partner process in a professional services firm: How women are disadvantaged. British Journal of Managemen, 19(s1), S65-S74. doi:10.1111/j.1467-8551. 2008.00572.x 
Leung, A. (2011). Motherhood and entrepreneurship: Gender role identity as a resource. International Journal of Gender and Entrepreneurship, 3(3), 254-264. doi:10.1108/17566261111169331

Lewis, K. V. (2015). The entrepreneurship motherhood nexus. Career Development International, 20(1), 21-37. doi:CDI-07-2014-0090

Lindo, M. R., Cardoso, P. M., Rodrigues, M. E., \& Wetzel, U. (2007). Vida pessoal e vida profissional: Os desafios de equilíbrio para mulheres empreendedoras do Rio de Janeiro. Revista de Administração Contemporânea, 1(1), 1-15.

Mainiero, L. A., \& Sullivan, S. E. (2005). Kaleidoscope careers: An alternate explanation for the "opt-out" revolution. The Academy of Management Executive, 19(1), 106-123. doi:10.5465/AME.2005.15841962

Marques, A. P., \& Moreira, R. (2011). Transição para o mercado de trabalho: Empreendedorismo numa perspectiva de género. Proceedings of the Encontro Nacional de Sociologia Industrial das Organizações e do Trabalho Emprego e Coesão Social, Lisboa, Portugal, XIV.

McGowan, P., Redeker, C. L., Cooper, S. Y., \& Greenan, K. (2012). Female entrepreneurship and the management of business and domestic roles: Motivations, expectations and realities. Entrepreneurship \& Regional Development, 24(1/2), 53-72. doi:10.1080/08985626.2012.637351

McKie, L., Biese, I., \& Jyrkinen, M. (2013). 'The best time is now!': The temporal and spatial dynamics of women opting in to self-employment. Gender, Work \& Organization, 20(2), 184-196. doi:10.1111/gwao.12019

Metz, I. (2005). Advancing the careers of women with children. Career Development International, 10(3), 228-245. doi:10.118/13620430510598346

Minniti, M. (2010). Female entrepreneurship and economic activity. European Journal of Development Research, 22(3), 294-312.

Minniti, M., \& Naudé, W. (2010). What do we know about the patterns and determinants of female entrepreneurship across countries? The European Journal of Development Research, 22(3), 277-293.

Okafor, C., \& Amalu, R. (2010). Entrepreneurial motivations as determinants of women entrepreneurship challenges. Petroleum - Gas University of Ploiesti Bulletin - Economic Sciences Series, 62 (2), 67-77.

Oltramari, A. P., \& Grisci, C. L. I. (2014). Carreira e família na sociedade líquido-moderna. Revista de Administração Mackenzie, 15(1), 15-48. doi:10.590/S1678-69712014000100002 
Parasuraman, S., \& Greenhaus, J. H. (1997). The changing world of work and family. In S., Parasuraman, \& J. H., Greenhaus (Eds.), Integrating work and family: Challenges and choices for a changing world. Westport, CT: Greenwood Publishing.

Piszczek, M. M., \& Berg, P. (2014). Expanding the boundaries of boundary theory: Regulative institutions and work-family role management. Human Relations, 67(12), 1491-1512. doi:10.1177/0018726714524241

Riessman, C. K., \& Quinney, L. (2005). Narrative in social work. Qualitative Social Work, 4(4), 391-412. doi:10.1177/1473325005058643

Røsen, M. (2014). Children and family: A barrier or an incentive to female self-employment in Norway? International Labour Review, 153(2), 337-349. doi:10.1111/j.1564-913X.2014.00207.x

Schütze, F. (2010). Pesquisa biográfica e entrevista narrativa. In W., Weller, \& N., Pfaff (Orgs.), Metodologias da pesquisa qualitativa em educação: Teoria e prática (pp. 210-222). Petrópolis, RJ: Vozes.

Schwartz, E. (1976). Entrepreneurship: A new female frontier. Journal of Contemporary Business, 5(1), 47-76.

Silva, J. R. G., \& Vergara, S. C. (2003). Sentimentos, subjetividade e supostas resistências à mudança organizacional. Revista de Administração de Empresas, 43(3), 10-21.

Singh, G., \& DeNoble, A. (2003). Early retirees as the next generation of entrepreneurs. Entrepreneurship Theory and Practice, 27(3), 207-226. doi:10.1111/1540-8520.t01-1-00001

Stefanović, S., \& Stošić, D. (2012). Specifics and challenges of female entrepreneurship. Economic Themes, 50(3), 327-343.

Terjesen, S. (2005). Senior women managers' transition to entrepreneurship. Career Development International, 10(3), 246-259. doi:10.1108/136204305 10598355

Vale, G. V., Serafim, A. F., \& Teodósio, A. S. S. (2011). Gênero, imersão e empreendedorismo: Sexo frágil, laços fortes? Revista de Administração Contemporânea, 15(4), 632-649. doi:10.1590/S1415-65552011000400005

Vieira, J. A. (2005). A identidade da mulher na modernidade. Documentação de Estudos em Linguística Teórica e Aplicada, 21, 207-238. doi:10.1590/S010244502005000300012

Vasconcelos, I. F. G., Mascarenhas, A. O., \& Zacarelli, L. M. (2006). As percepções subjetivas do tempo nas organizações e a mudança organizacional: Uma análise comparativa da Daimler Chrysler e da Bull França. Organizações E Sociedade, 13(36), 65-83. doi:10.1590/S1984-92302006000100004 
Zhang, Q. F., \& Pan, Z. (2012). Women's entry into self-employment in urban China: The role of family in creating gendered mobility patterns. World Development, 40(6), 1201-1212. doi:10.1016/j.worlddev.2011.11.004

\section{) АUTHOR NOTE}

Gisélia F. Ferreira, Fundação Instituto Capixaba de Pesquisas em Contabilidade, Economia e Finanças (Fucape), ORCID:orcid.org/0000-0002-9992-6529; Sérgio A. P. Bastos, Fundação Instituto Capixaba de Pesquisas em Contabilidade, Economia e Finanças (Fucape), ORCID: orcid.org/0000-0002-5697-3624; Marcia J. d'Angelo, Fundação Instituto Capixaba de Pesquisas em Contabilidade, Economia e Finanças (Fucape), ORCID:orcid.org/0000-0003-1436-5812.

Gisélia F. Ferreira is now Executive Professor at Fundação Getúlio Vargas (FGV-Vitória) online.

Correspondence concerning this article should be addressed to Sérgio A. P. Bastos, Avenida Fernando Ferrari, 1358, Boa Vista, Vitória, ES, Brazil, CEP 29075-505.

E-mail: sbastos@fucape.br

\section{EDITORIAL BOARD}

Editor-in-chief

Silvio Popadiuk

Associated Editor Luciana M. C. Silva

Technical Support Vitória B. S. Silva

\section{EDITORIAL PRODUCTION}

Publishing Coordination Irina Migliari

Editorial Trainee

Maria Luiza Vanz

Copyeditor

Irina Migliari
Language Editor
Daniel Leão

Layout Designer

Emap

Graphic Designer

Libro 